\title{
ECONOMIC IMPACT OF COVID-19 ON HIGH SCHOOL TEACHERS; AN ASSESSMENT OF TEACHERS ON PRIVATE HIGH SCHOOLS FROM THE KATHMANDU METROPOLITAN, NEPAL
}

\author{
Nanu Maya Devkota*
}

\begin{abstract}
:
The private sector education improving the overall education system has created a large employment opportunity for educated manpower of secondary-level education in Nepal. But unfortunately, there is almost no provision of economic, social, and employment-wise security and insurance for this human resources. Hence, this group of manpower gets heavily quivered by external natural and social factors like the COVID-19 pandemic.
\end{abstract}

Being bound within Kathmandu metropolitan, this research has aimed to study the effect of COVID-19 on employment, income, and savings of the teachers involved in private high school (grade 11 and 12). This situation has arisen from the fact that many intuitions have been fully or partially shut down due to the global pandemic.

This study is quantitative research based on primary data. For this, the purposive sampling technique is used. This study computes the data through the questionnaire and the direct interview taken by 50 samples.

Using paired t-test, a significant difference has been observed in the employment, income, and savings of the teachers, pre and during COVID backed and further evaluated by other descriptive statistics. The percentage change in meaningful employment, mean income and mean savings has been observed as $69.25 \%, 40.50 \%$, and $86.95 \%$ respectively through the analysis of data.

On evaluating the economic condition of teachers of private institutions, although it has been acceptable in sound environmental conditions, in extreme conditions like COVID-19, their economic condition is highly likely to get deteriorated. This deterioration is backed by the observation of this research and is highly significant.

This research helps to forecast and manage the possible economic fluctuation of teachers, that may arise during a crisis like COVID-19. Furthermore, this research also implicates the government and concerned institutions to derive policies such as social security funds and other schemes for teachers to fortify their economic condition during abnormal situations.

Keywords: Private high school, High school teachers, Employment, Income, Savings. Assistant Professor of Saraswati Multiple Campus (Humanities Faculty, Economics Department), Tribhuvan
University, Nepal 


\section{Indroduction}

The SARS-CoV2 caused by Coronavirus named COVID 19, reported in Wuhan China in December 2019 for the first, is seen as a disaster in human life in 2020 throughout the world (Marinoni, Land, \& Jensen, 2020). Now 223 countries throughout the world have confirmed active cases caused by a coronavirus (WHO, 2021, Feb.1). WHO had declared this as a pandemic on 11 March 2020 (Cucinotta \& Vanelli, 2020). The $1^{\text {st }}$ case of covid19 in Nepal was identified on January 25, 2020, after a Nepali student returning from the city of Wuhan, China (Bastola, Sah, Lal, \& Jha, 2020). It has affected social, cultural, economic, political, education, health, and so on of human life throughout the world, and among this all-sectors education is one in which significant negative effects have been made with the onset of the COVID-19 pandemic (Dawadi, Giri, \& Simkhada, Impact of COVID -19 on the education sector in Nepal - challenges and coping strategies, 2020). According to a report given by the world bank in 28 march 2020, more than 1.6 billion children and youth were out of school in 161 countries, which is almost $80 \%$ of the world's enrolled students (bank, 2020). Due to the closure of educational institutions all people who are either directly or indirectly linked with this sector are affected much (Marinoni, Land, \& Jensen, 2020). A report by UNICEF has shown that nearly 8 million children were out of school and the unemployment problem has increased significantly in 2020 (UNICEF, 2020). In the case of Nepal while in comparison with the public sector, teachers and administrative staff of more than 6000 private education institutions have lost their job and income after mid-April (Upadhyaya, 2020, July-31). In the case of high school education, the number of students enrolled has decreased significantly and those who got enrolled have also not paid their regular fees as before (Varly, 2020). On the other hand, many school managements have managed a large number of students within the same virtual class. Due to all these factors teachers who were engaged in private schools are suffering more either due to a reduction in their employment and regular salary from the institution. Santhagat Vidyalaya Schickshak Union (Institutional School Teacher Union - ISTU) had organized a press conference on 20th September 2020 to address the unpaid and dismissed problem of private school teachers and education staff during the pandemic. The president of ISTU claimed that more than 3000 teachers and staff have been dismissed across the country during this pandemic. Most of the private educational institutions have not paid salaries to their employees and at the same time, the government also failed to provide adequate support and make policies to solve the unpaid and dismissed problems of the private teachers and educational staff (Education International, 2020). Also, this has created a huge discrepancy in the pre-COVID and post-COVID employment and income of teachers, especially on the secondary level education.

By the onset of the COVID-19 outbreak, the conventional method of learning and teaching activities was put to a halt. After the disturbances of physical classes, many countries have changed their teaching -learning activities to virtual classes (Qazi, Naseer, \& Qazi, 2020). The Nepal government also accepted the alternative way of teaching than the physical classes as the regular academic session and permitted to run the virtual classes through online, TV/ Radio and so on. Still, to date, the virtual learning process using online learning programs are being effective. However, before the outbreak, many teachers in Nepal without appropriate training and workshops were not familiar with the usage of this digital equipment. This has created a greater challenge in the education system of Nepal. Thus, the technologizing of the education system is seen both as an opportunity and challenge for the Nepalese education system. Also, the 
implementation of ICT and other education-related policies since 2000 has been weak and unremarkable (Dawadi, Giri, \& Simkhada, Impact of COVID -19 on the education sector in Nepal - challenges and coping strategies, 2020). Furthermore, a loophole in the education system has encouraged private institutions to completely dismiss the contract of the teachers and recruit a completely new face just based on digital friendliness.

In the time when COVID -19 has negatively impacted the entirety of the educational sector, the ministry of education under the Nepal government has launched a "Student Learning Facilitation Guide." (Guide, 2020). This directory aims in continuing the disturbed education of students through a circumstantial approach. In article 22 of the directory under the topic Educational institution management committee and their responsibility, in the sub-article THA ( $\boldsymbol{\delta}$ - L in English letter numbering) the provision for the approval of fee for the easement of learning is granted via local executive body has been included. Similarly, in article 30, it has been incorporated that institutions will be able to collect the fee in accordance with existing law and after the approval of local bodies. Although these two provisions might sound sufficient for schools and colleges, there are no provisions regarding alternative education methods and the directory seems completely vague. This has created a chaotic mindset between the students and the institutions regarding the fee and in turn, the educational institutions blaming this fact are refusing to provide teachers and staff with appropriate wages. Ultimately, a direct impact has been observed in the employment and income of these teachers and staff.

COVID-19 has a severe effect on every field of human life. Among them, people involved in teaching at private schools may lose their job significantly because of the lockdown and long injunction than after contrived by the Nepal government. The researcher raises the research questions; whether there is an impact on employment, income, and savings of private school's teachers due to the appearance of COVID-19 or not?

The study aims to find the economic impact caused by the COVID-19 pandemic on high schools' teachers engaged in private schools located in Kathmandu Metropolitan. Furthermore, the economic impact is studied on the headings of employment situations based on the number of classes taken by the teachers, monthly income situation, and monthly savings condition only.

This study is done by splitting the whole study into six parts. Within the first part, the background of the study, research questions, research objectives are included. This part shows the overall condensation of the study. The second part of the study is the literature review. Within it, books, journal articles, blogs, writings from the websites, etc., are studied and reviewed. Furthermore, a theoretical and conceptual framework is also prepared, which makes a clear guideline for the whole analysis part of this study. The third part consists of research methodology and methods. Under which, research design, study area, sampling method, and sample size are mentioned. Similarly, the fourth part of the study explores the result from the data analysis. The data analysis has been broken down into two sections; the descriptive analysis and the hypothesis testing. In the fifth part of the research, discussion about the findings from the present data analysis are incorporated with other similar findings made in the past and the established theories derived by the renowned economists. Finally, the sixth part is the conclusion part, in which the conclusion of the study with the theoretical and practical implications are presented. It suggests a new study area for the future. At last, the bibliography is written in the latest APA format. 


\section{Literature Review}

\section{Situation of secondary level education in private sector}

The education system of Nepal has been primarily divided into 4 categories. Primary education, lower secondary education, secondary education, and university level education. Under secondary level education grades 9 to 12 are incorporated (Nuffic, 2015). In Nepal, 4137 institutions operating for the grade 11 and 12 naming them as the +2 institutions earlier (National Examination Board Nepal, 2019). But, Although, the name +2 has been eradicated and instead has been merged with the secondary level, the distinction of these institutions still prevails. Furthermore, there exists the upper hand of the private sector in the investment and functioning of the secondary level education and the numbers of institutions opened on private investment are quite substantial. The secondary level of education in Nepal hence has contributed significantly in providing contract-based job opportunities for the majority of the teachers in private high school. Private schools are those which are operated either by the tuition fees paid by the students or by the support made by different nonpublic sources, where the class size is small, teachers are more competent, parents are more aware of their children education, more efficient management, etc. which results in the overall better performance (Smith, Young, Bae, \& Choy, 1997). Since private sector teachers receive salaries directly from the school management and the majority of the private institutions are profit-oriented, there are almost irregularity and insecurity of regular employment and income for the employees. However, due to the poor performance of existing public schools, the importance and need of private schools are increasing in the context of Nepal (Koirala, 2015). Information from the 2020 report of 'teacher taskforce' shows that teachers were not paid salaries regularly or unpaid. Not only in Nepal, same situation is seen in other countries also. A study made by Varly in Africa shows that during school closure, many African countries were unable to or suspended their salaries paid to the contract teachers but some countries like Ghana and Sierra Leone paid salaries by reducing their payments. It was due to school closure and schools being unable to collect the tuition fees at the time since fees are the only source of income for private schools (Varly, 2020).

A research on 'Income and implication of teachers performance to improve the quality of education in the elementary school of Surabaya', by Susbroto in 2013 in Indonesia showed that the increase in income in the form of salary or subsidy as well as an honorarium of the teachers have a positive impact on the performance of the teachers. Furthermore, the quality of education depends on the performance of the teachers largely (Subroto, 2012). Even though this result shows the positive relationship between teacher's income, their performance, and quality of education, but in the context of Nepal, it seems contradictory. In Nepal, the performance of the teachers and the quality of education are measured based on of SEE results. The SEE results for the year 2076 show that the students from the private school can secure a higher score in their SEE examination than the students of public school (Metropolitian, Kathmandu, 2077). On the other hand, it is found that the majority of the teachers of private schools get less salaries than the public-school teachers. Also, the inert behavior of the government has led to weak policies and plans in this sector. 


\section{Significance of the study}

Although during this pandemic many scholars made their contribution to the study of the socioeconomic impact of COVID-19 and its impact on the education sector overall, only a few studies have been made focusing on the teachers. So, to provide some in-depth economic analysis on the condition of private schools' teachers during the COVID-19, the parameters of employment, income, and savings have been used in this study. Furthermore, the understanding of employment and income of teachers opens a broad space for understanding other socio-economic conditions of the teachers which ultimately helps in improving their living standards as a whole.

\section{Theoretical analysis and Conceptual framework}

Loss of employment due to COVID-19 is likely to cause the loss of income (production function analysis). It is because, according to the Keynesian employment theory, a rise in income leads to a rise in income or output successively until the economy reaches a full employment situation. Again, according to the Keynesian psychological law of consumption, a rise in income, leads to increase in both savings and consumption. This law further justifies that due to an increase in income, consumption increases less proportionately than to the increase in income. Due to this, a significant loss in savings is obvious due to a fall in income caused by COVID-19 (Keynesian psychological law of consumption analysis). Ultimately, unemployment is likely to cause a loss in saving. In this research, the researcher set the workflow as COVID-19, the root cause for increased unemployment, loss of income and further loss of savings successively.

\section{RESEARCH METHODOLOGY}

Research design - This study followed a descriptive analysis. Descriptive research is a quantitative research strategy in which the researcher used the collected data to describe the characteristics of the total population understudied. It includes nominal, ordinal, ratio and interval variables and measures central tendency, dispersion, frequency measures and position (Kaur, Stoltzfus, \& Yellapu, 2018). The descriptive analysis is used to answer the questions about who, where, when and to what extend the variation obtained in the population under studied. To determine whether a significant difference in income, employment, and savings is made due to COVID-19 or not, I used a purposive sampling technique by ensuring the reliability of informants. Under this method, 50 teachers are selected from the different private high schools located in Kathmandu Metropolitan to get the answer to my research questions. Since this research is based on the empirical study about the current situation, primary data are preferred to solve the research question. The primary data are collected by using a digital questionnaire and further direct interview method. The collected data are proceeds by using different statistical tools. Since this research has two types of questions i.e., Descriptive and inferential, statistical tools like descriptive statistics, paired T-test is used to get the results.

Study Area and Population of the Study - The population of the study was made up of all the Higher Secondary teachers of private +2 high schools located in Kathmandu Metropolitan. It is because there are large numbers of high schools in the Kathmandu metropolitan as compared to other local levels. Furthermore, out of 561 high schools in Kathmandu, 500 are private (Metropolitian, Kathmandu, 2077). The population of the study was considered the whole high 
school teachers of private +2 in the Kathmandu Metropolitan. It was estimated that about 3000 teachers were involved in this area directly. Repetition of teachers for several institutions was the common feature so that about 50 percent of teachers out of 4000 (only 2000) were taken as the total population for this study.

Sampling and sample size - This research is based on the data obtained by the purposive sampling method. Using digital surveying procedures, the data has been recorded, and using different parameters, the income and employment condition of teachers during the pandemic has been analyzed in this research. The data aimed to capture the immediate effects of the pandemic on the Higher secondary level teachers of a private school of KTM with regards to their employment, income, and savings from march 2020 to October 2020. For this task, the respondents were selected randomly from the sample area. In this study, Primary data collected from the 50 respondents through a mailed questionnaire method, and the secondary data obtained from different sources are used to complete the work.

The researcher must respect the main principle of academic ethics of individual confidentiality and privacy in data collections. In this study, the ethical aspects of privacy of sampling teachers, schools, their income level, employment condition, savings, and other demographic and social information have been maintained. It has also been assured that the collected data will be properly used only by the researcher for purposive objectives and not for others purpose

Hypothesis - In this research the researcher has three claims

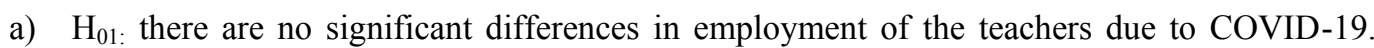
$\mathrm{H}_{01 \mathrm{a}}$ : there are no significant differences in employment by gender of teachers due to COVID19.

b) $\mathrm{H}_{02}$ : there is no significant difference in income of the teachers due to COVID-19. $\mathrm{H}_{02 \mathrm{a}}$ : there are no significant differences in income by gender of teachers due to COVID-19.

c) $\mathrm{H}_{03}$ : there is no significant difference in savings of the teachers due to COVID-19. $\mathrm{H}_{03 \mathrm{a}}$ there are no significant differences in savings by gender of the teachers due to COVID-19.

\section{Duration of the study}

The main objective of this research is to assess the economic impact of COVID-19 on Secondary level private school teachers in Kathmandu Metropolitan between March 2020 October 2020. During that period, all schools are closed down due to lockdown and teaching learning activities are changed in virtual classes from the physical classes

\section{Empirical result and interpretation Demographic Features of Respondents}

Among the respondents, $60.4 \%$ were male whereas $39.6 \%$ were female. The marital status show that most of the teachers were married (72.9\%) are married and have nuclear family (83 .4\%). Among teachers most of them $(64.4 \%)$ have no own house in Kathmandu valley and they live in 
rent. Furthermore, many of them (70.8\%) have no alternative source of income except the teaching profession. Although most of the teachers have no alternative source of income, a very smaller number of teachers $(6.3 \%)$ from private school had got the regular salary during pandemic. Among the teachers, about (54.2\%) had not got regular salary and about (39.6\%) had got partially. Thus, the COVID-19 may have greater negative impact on their economic conditions among the teachers.

Table 1: Demographic features of respondents

\begin{tabular}{|c|c|c|}
\hline Variable & & Respondents \\
\hline Gender & Male & $29(60.4 \%)$ \\
\hline & Female & $19(39.6 \%)$ \\
\hline Marital Status & Married & $35(72.9 \%)$ \\
\hline & Unmarried & $13(27.1 \%)$ \\
\hline Housing condition in & Own house & $17(35.4 \%)$ \\
\hline Katmandu & Rent or others & $31(64.6 \%)$ \\
\hline Household & & \\
\hline composition & Nuclear family & $40(83.4 \%)$ \\
\hline & Joint family & $8(16.7 \%)$ \\
\hline Source of income & Teaching only & $34(70.8 \%)$ \\
\hline & Teaching and other sources & $14(29.2 \%)$ \\
\hline Condition of salary & Regularly got & $3(6.3 \%)$ \\
\hline received during & Not regularly got & $26(54.2 \%)$ \\
\hline pandemic & Partially got & $19(39.6 \%)$ \\
\hline
\end{tabular}

\section{Results of Descriptive analysis}

The following table depicts the descriptive analysis of employment, income and savings of the respondents. It observed the mean values and the percentage change in mean values of observed variables between before and during COVID-19 pandemic.

\section{Table 2: Frequency Distribution Table of all Respondents}

\begin{tabular}{|l|l|l|}
\hline Observation items & No. of respondent & Mean \\
\hline Number of classes per week before COVID-19 & 46 & 28.80 \\
\hline Number of classes per week during COVID-19 & 46 & 9.41 \\
\hline Percent change in mean number of classes & & $69.25 \%$ \\
\hline Monthly income before COVID-19 (in Rs.) & 44 & 41056.82 \\
\hline Monthly income during COVID19(in Rs.) & 44 & 24427.685 \\
\hline Percent change in mean monthly income & & $40.503 \%$ \\
\hline Monthly Savings before COVID-19 (in Rs.) & 44 & 20197.73 \\
\hline Monthly savings during COVID-19 (in Rs.) & 44 & 2636.36 \\
\hline Percent change in mean monthly savings & & $86.95 \%$ \\
\hline
\end{tabular}


Table 2 presents a shrink in numbers of per week classes taken by the private high school teachers, fall down in income level of the teachers and the fall down in savings amount of the teachers before the COVID-19 and during COVID-19 (i.e., March to November 2019). The above table shows that the mean no. of classes taken by the teachers per week are decreased largely. Mean value of classes per week has decreased by $(28.80-9.41)=69.25 \%$ due to COVID19 pandemic. Also, the table shows that the mean monthly income of the teachers has decreased. Mean value of monthly income is decreased by $(41056.82-24427.685)=16,629.135 \mathrm{Rs}$, this is $40.503 \%$ fall in income due to decrease in employment caused by COVID-19 pandemic. Furthermore, the tables show that the mean monthly savings of the teachers are decreased largely. The table presents that the mean value of monthly savings has decreased by $(20197.73-2636.36)=$ $86.95 \%$ due to COVID-19 pandemic.

\section{Table :3 Frequency Distribution Table of Gender Groups}

\begin{tabular}{|c|c|c|c|c|c|c|c|c|c|c|c|c|}
\hline \multirow[t]{2}{*}{ Gender } & \multicolumn{2}{|c|}{$\begin{array}{c}\text { No. of } \\
\text { classes per } \\
\text { week } \\
\text { before } \\
\text { pandemic }\end{array}$} & \multicolumn{2}{|c|}{$\begin{array}{c}\text { No. of } \\
\text { classes per } \\
\text { week during } \\
\text { pandemic }\end{array}$} & \multicolumn{2}{|c|}{$\begin{array}{l}\text { Monthly } \\
\text { income } \\
\text { before } \\
\text { pandemic }\end{array}$} & \multicolumn{2}{|c|}{$\begin{array}{l}\text { Monthly } \\
\text { income } \\
\text { during } \\
\text { pandemic }\end{array}$} & \multicolumn{2}{|c|}{$\begin{array}{c}\text { Monthly } \\
\text { savings before } \\
\text { pandemic }\end{array}$} & \multicolumn{2}{|c|}{$\begin{array}{c}\text { Monthly } \\
\text { savings during } \\
\text { pandemic }\end{array}$} \\
\hline & Number & Mean & Number & Mean & Number & Mean & number & Mean & Number & Mean & Number & Mean \\
\hline Male & 28 & 33.61 & 28 & 13.89 & 29 & 49051.7 & 29 & 15993.2 & 26 & 30846.2 & 26 & 3115.38 \\
\hline Female & 18 & 21.33 & 18 & 2.44 & 15 & 25600.0 & 15 & 6166.7 & 18 & 4816.67 & 18 & 1944.44 \\
\hline Total & 46 & & 46 & & 44 & & 44 & & 44 & & 44 & \\
\hline
\end{tabular}

Table 3 presents the mean no. of classes per week, mean monthly income and mean monthly savings for both male and female teachers. This table shows that the number of classes has decreased largely. Mean value of classes per week for male teachers is decreased by (33.61$13.89)=58.67 \%$ due to COVID-19 pandemic whereas Mean value of classes per week for female teachers is decreased by $(21.33-2.44)=88.56 \%$. The table shows that the mean income for both male teachers and female teachers are decreased. Mean value of monthly income for male teachers is decreased by $(49051.72-15993.17)=67.39 \%$ due to COVID-19 pandemic whereas Mean value of monthly income for female teachers is decreased by $(25600.00-6166.67)=$ $75.91 \%$. Furthermore, the mean savings for both male teachers and female teachers are decreased. Mean value of monthly savings for male teachers is decreased by $(30846.15-3115.38)=89.90 \%$ whereas Mean value of monthly savings for female teachers is decreased by $(4816.67-1944.44)=$ $59.63 \%$ due to COVID-19 pandemic. 


\section{Results of hypothesis testing and test of significant}

Table 4: Hypothesis Testing About Employment Situation, income situation and savings situation for all Teachers Between the Before and During COVID-19

\begin{tabular}{|l|l|l|l|}
\hline & $\begin{array}{l}\text { Degree of } \\
\text { freedom }\end{array}$ & T-Value & P-Value \\
\hline $\begin{array}{l}\text { No. of classes per week before COVID19 - } \\
\text { No. of classes per week during COVID-19 }\end{array}$ & 45 & 10.616 & 0.000 \\
\hline $\begin{array}{l}\text { Monthly income before COVID-19 - Monthly } \\
\text { income during COVID-19 }\end{array}$ & 43 & 10.360 & 0.000 \\
\hline $\begin{array}{l}\text { Monthly savings before COVID-19 - Monthly } \\
\text { savings during COVID-19 }\end{array}$ & 43 & 3.676 & 0.001 \\
\hline
\end{tabular}

As table 4, P-value for the difference in number of classes before and during the COVID-19 is less than 0.05 (i.e., 0.000), the null hypothesis is rejected. So, the T-test tells us that there is a significant difference between the no. of classes taken by the teachers before COVID-19and during COVID-19. It further tells us that the employment decreases significantly due to the COVID-19 pandemic. Similarly, P-value for the difference in monthly income earned by the teachers is less than 0.05 (i.e., 0.000), the null hypothesis is rejected. So, the T-test tells us that there is a significant difference between the monthly income of the teachers before COVID-19 and during COVID-19. Furthermore, the P-value for the difference in monthly savings of the teachers is also less than 0.05 (i.e., 0.001), the null hypothesis is rejected. So, the T-test tells us that there is a significant difference between the monthly savings of the teachers before COVID19 and during COVID-19.

Table :5 Hypothesis Testing of Employment Situation, income situation and savings situation for Male and Female Teachers Between Before and During COVID-19.

\begin{tabular}{|l|l|l|l|l|l|l|}
\hline & \multicolumn{2}{|l|}{ Male } & \multicolumn{2}{l|}{ Female } \\
\cline { 2 - 6 } & $\begin{array}{l}\text { Degree of } \\
\text { freedom }\end{array}$ & T-Value & P-Value & $\begin{array}{l}\text { Degree of } \\
\text { freedom }\end{array}$ & $\begin{array}{l}\text { T- } \\
\text { Value }\end{array}$ & $\begin{array}{l}\text { P- } \\
\text { Value }\end{array}$ \\
\hline $\begin{array}{l}\text { No. of classes per week } \\
\text { before COVID-19- No. } \\
\text { of classes per week } \\
\text { during COVID-19 }\end{array}$ & 27 & 7.643 & .000 & 17 & 7.641 & .000 \\
\hline
\end{tabular}




\begin{tabular}{|l|l|l|l|l|l|l|}
\hline $\begin{array}{l}\text { Monthly income before } \\
\text { covid19- } \begin{array}{r}\text { Monthly } \\
\text { income during COVID- } \\
19\end{array}\end{array}$ & 9.403 & .000 & 14 & 5.797 & .000 \\
\hline $\begin{array}{l}\text { Monthly savings before } \\
\text { covid19- 25 Monthly } \\
\text { savings during COVID- } \\
19\end{array}$ & & 3.711 & .001 & 17 & 2.858 & .011 \\
\hline
\end{tabular}

As table 5, the P-value for both male and female teachers regarding their number of classes are less than 0.05 (i.e., 0.000 ), the null hypothesis is rejected. So, the T-test tells us that there is a significant difference between the no. of classes taken by both male and female teachers before covid19 and during COVID-19. Similarly, the P-value for both male and female teachers about their monthly income are less than 0.05 (i.e., 0.000 ), the null hypothesis is rejected. So, the T-test tells us that there is a significant difference in monthly income earned by the male and female teachers between before and during covid19. Again, P-value for male teachers regarding their monthly savings is less than 0.05 (i.e., 0.001), the null hypothesis is rejected. So, the T-test tells us that there is a significant difference in monthly savings among the male teachers between before and during COVID-19. Similarly, the P- value for the female teachers regarding their monthly savings also less than 0.05 (i.e., 0.011), the null hypothesis is rejected. So, the T-test shows that there is a significant difference in the monthly savings of female teachers between before and during COVID-19 pandemic.

\section{Findings and Discussion}

The study asserts the devastating effects of COVID-19 pandemic on the economic condition of the private schools' teachers. Since the main purpose of this study is to explore and analyze the economic impact of COVID-19 on the private Schools' high school teachers who teaches in grade 11 and 12, in this research number of classes taken per week is considered as employment condition, monthly income and monthly savings of the teacher as the measuring tools. The findings show three important points of discussion.

First, the result shows that the employment was decreased significantly due to the COVID-19 pandemic and school closure thereafter. As the P-value is 0.000 which is less than 0.05 , t-test revealed that the null hypothesis (Ho) is rejected and the alternative hypothesis is accepted. It means that the employment reduces significantly and the teachers are suffering from the unemployment problems greatly. The descriptive analysis shows that the no. of classes per week is decreased by $69.25 \%$. Furthermore, by splitting teachers according to their gender, P-value for both male and female teachers are less than 0.05 (i.e., 0.000), there is a significant impact on employment for both groups. The result tells that the COVID-19 has created huge unemployment problems among the teachers. This finding is assertion with the line by Onyema and team (Onyema, Eucheria, \& Obafemi, 2020) that the coronavirus pandemic has multiple effect on education sectors as; learning disruption, job loss in the education sector, increase in students' debts, reduced funding for education, research constraints, and loss of learning interests among 
learners. Same kind of result was found in a rapid assessment study done by UNDP. The result of UNDP shows that the monthly income of MSMEs decreased by 95\% during the 2 months of lock down, about $80 \%$ of MSMEs are closed down temporarily and 3 people in each 5 people have lost their job. Analyzing gender, it was found that $28 \%$ men and $41 \%$ women have lost their job during the observation period. The study further shows that those who did not lost their job also are not getting salary regularly and are suffering from wage-cut (UNDP, Nepal, 2020).

Second, analysis of the impact on income is made by comparing the monthly income before the emergence of COVID-19 pandemic and during this Pandemic. Results from the analysis impact on income due to coronavirus and school closure shows that the income level of the private high schools' teachers has decreased significantly. Result shows that the P-value is 0.000 , which is less than 0.05 , tells us that the income of the teachers decreases significantly. The descriptive analysis shows that the monthly income is decreased by $40.503 \%$. Moreover, separate study about changes in income both on male teachers and female teachers also shows the highly significant differences in income. It is because, in both gender cases, P-value is 0.000 which is less than 0.05 . Furthermore, the descriptive analysis shows that the monthly income of male teachers is decreased by $67.39 \%$ and female teachers is decreased by $75.91 \%$. This tells us that income of female teachers has decreased largely than the income of male teachers. The result of this study also in the same line of Views of senior policy analyst Shelby Carvalho and Co-director of Education Policy and Senior Policy Fellow wrote on their blog about the reduction of salary and employment of the contract teachers of the private school. Furthermore, they wrote that the Nigeria government launched a package to pay more than 10000 contract teachers who had missed salary for the three months due to COVID-19 pandemic (Carvalho \& Hares, 2020) . A report given by ILO also is also shown the same kind of result. The report estimated that about $60 \%$ income is decreased from the informal sector is decreased in the global context and the value is more than $50 \%$ in the context of Nepal (International labour organization, 2020).

Third, by the result on savings showed that the savings also decreased largely i.e.by $86.95 \%$. Since the P-value is 0.001 , it shows that the monthly savings is decreased significantly. The follow up interview taken by the respondent found that the main reasons for the decrease in savings is due to the unemployment and further fall in income. The current study supports the existing Keynesian psychological law of consumption. In the law J.M. Keynes justify the proposition that the increase in income leads to increase in both consumption and savings (Ahuja, 2018). On the contrary the decrease in income leads to decrease in savings also. Thus, the study match with the proposition of Keynesian psychological law of consumption. Furthermore, the decrease in savings in case of male teachers $(89.90 \%)$ is greater than the female teacher $(59.63 \%)$. A study made on "Gender Differences in Personal Saving Behaviors" by Patti also in the same line of this result, though the study was made only among the unmarried or live alone people (Fisher, 2020). 


\section{Conclusion}

This research has shown the economic effect of COVID19 on the secondary level teachers of Kathmandu metropolitan. The economic effect has been broken down into 3 main indications viz. employment, income and savings. And for the statistical answer on, is there significant difference? And how much has it been changed? - paired t-test result and the descriptive statistical methods has been used. This paper has displayed how COVID-19 has impacted negatively on teachers' economic condition on the basis of analysis of collected data. All the three indications have been observed to have reduced significantly. In case of employment, it has been observed that, female teachers are more affected than the male teachers. For income, the story repeats on itself, making female teachers more impacted than the male teachers. In contrary to that, evaluating the reduced saving, male teachers had more reduced savings than the female teachers. On evaluating these facts, if can be concluded that, people working on private education sector in Nepal has a very uncertain and unsecured employment and way of earning. From this research it can be said that, prevention of these circumstances during abnormal periods should be planned and organized during the regular working periods i.e., normal periods. This reduces the chances of heavy deterioration of economic condition of teachers in uncertain times. Furthermore, the governmental policies regarding difficult times and private education sector must be fortified and should be accordingly implemented on time. This creates a healthy scenario and mutual relationship between private employee and employers.

This research is primarily focused on the economic impact of COVID19 on teachers. However, this can be further expanded as the effect on the social and metal welfare of teachers due to this economic impact. Similarly, differences in observations of male and female teachers are recorded in this research. Reasons beside these differences can be further explored and studied in depth.

\section{References}

Ahuja, H. (2018). Macro economics theories and policies (20th ed.). New Delhi, India: S Chanda and Company Limited.

Bastola, A., Sah, R., Lal, B. K., \& Jha, R. (2020, March 01). The first 2019 novel coronavirus case in Nepal. The Lancet, 20(3), 279-280. doi:https://doi.org/10.1016/S14733099(20)30067-0

Carvalho, S., \& Hares, S. (2020, November 24). The economic shock of COVID-19 may hit private school and contract teachers hardest. Independent research for global prosperity.

Cucinotta, D., \& Vanelli, M. (2020). WHO declares COVID-19 a pandemic. Acta bio-medica, 91$N(4)$. doi:10.23750/abm.v91i1.9397

Dawadi, S., Giri, R., \& Simkhada, P. (2020). Impact of COVID -19 on the education sector in Nepal - challenges and coping strategies. doi:10.31124/advance.12344336.v1

Dawadi, S., Giri, R., \& Simkhada, P. (2020). Impact of COVID-19 on the Education Sector in Nepal - Challenges and Coping Strategies. doi:https://doi.org/10.31124/advance.12344336.v1 
Education International. (2020, September 25). Nepal: Education union fights for private teachers and education staff unpaid or dismissed during pandemic. Kathmandu: Education International. From https://www.ei-ie.org

Fisher, P. (2020, 01 01). Gender differences in personal saving behaviors. Journal of financial counseling and planning, 21(1), 14-24.

Giorgio Marinoni, H. v. (2020). 1, rue Millis F 75732 Paris cedex 15France: International Association of Universities (IAU). From https://www.iauaiu.net/IMG/pdf/iau_covid19_and_he_survey_report_final_may_2020.pdf

Guide. (2020). Student learning facilitation guide, 2077. Kathmandu, Nepal: Nepal government, ministry of education, science and technology. From https://www.collegenp.com/article/student-learning-facilitation-guide-2077/

International Association of Universities (IAU). (2020). The Impact of Covid19 on Higher Education Around the World. UNESCO House,1, rue Miollis F 75732, Paris cedex 15, France: International Association of Universities. doi:ISBN: 978-92-9002-212-1

International labour organization. (2020). COVID - 19 labour market impact in Nepal. Nepal: ILO. From https://www.ilo.org

Kaur, P., Stoltzfus, J., \& Yellapu, V. (2018). Descriptive Statistics. International Journal of Academic Medicine, 4(1), 60-63. doi:10.4103/IJAM.IJAM_7_18

Koirala, A. (2015). Debate on public and private schools in Nepal. International journal of management and social sciences, 2(1), 3-8. doi:10.3126/ijssm.v2i1.11882

Marinoni, G., Land, H. v., \& Jensen, T. (2020). The impact of COVID-19 on higher education around the world. France: International association of universities (IAU). From https://www.iau-aiu.net

Metropolitian, Kathmandu. (2077). महानगर शैक्षिक दर्पण. Kathmandu: Kathmandu Metropolitian.

National Examination Board Nepal. (2019). Sampresan. Bhaktapur: National Examination Board Nepal.

Nuffic. (2015). Education system Nepal. From www.nuffic.nl/en/home/copyright.

Onyema, E. M., Eucheria, N. C., \& Obafemi, F. A. (2020). Impact of coronavirus pandemic on education. Journal of education and practice, 11(13), 108-121. doi:10.7176/JEP/11-13-12

Qazi, A., Naseer, K., \& Qazi, J. (2020, December). Conventional to online education during COVID-19 pandemic: Do develop and underdeveloped nations cope alike. Econ Papers (Children and Youth Services Review), 119(C). doi:https://doi.org/10.1016/j.childyouth.2020.105582

Smith, T. M., Young, B. A., Bae, Y., \& Choy, S. P. (1997). The condition of education 1997. Washubgton,DC 20208-5574: National center for education statistics. From http://www.ed.gov/NCES 
Subroto, W. T. (2012, February). Income and implications of teacher performance to improve the quality of education in the elementary school of Surabaya. International journal of business, humanities and technology, 2(8), 112-122. From http://www.ijbhtnet.com

UNDP, Nepal. (2020). Three in five employees lost their jobs due to COVID-19 in Nepal. From https://www.np.undp.org

UNICEF. (2020). Nepal Appeal. From https://www.unicef.org/appeals/nepal

Upadhyaya, U. C. (2020, July-31). Impact of covid-19 on workers and employment in Nepal. National labour academy, Nepal.

Varly, P. (2020). How the COVID-19 pandemic is affecting contract teachers in sub-Saharan Africa. Africa: International task force on teachers for education 2030 (TTF). From https://teachertaskforce.org

WHO. (2021, Feb.1). Coronavirus disese (COVID 19) pandemic. WHO. From https://www.who.int 